(c) American Dairy Science Association, 2003.

\title{
Effects of Replacing Chopped Alfalfa Hay with Alfalfa Silage in a Total Mixed Ration on Production and Rumen Conditions of Lactating Dairy Cows
}

\author{
J. M. Calberry, ${ }^{\star}$ J. C. Plaizier, $†$ M. S. Einarson, $\dagger$ and B. W. McBride* \\ *Department of Animal and Poultry Science \\ University of Guelph, Guelph, ON, Canada N1G 2W1 \\ †Department of Animal Science \\ University of Manitoba, \\ Winnipeg, MB, Canada R3T 2N2
}

\begin{abstract}
The effects of replacing chopped alfalfa hay with alfalfa silage in a total mixed ration containing barley grain and corn silage on production and rumen conditions were investigated. Cows received three diets that all contained (dry matter basis) $38.5 \%$ barley grainbased energy supplement, $30.5 \%$ corn silage, $17.0 \%$ protein supplement, and $4.2 \%$ sunflower seeds. One diet contained (dry matter basis) $9.8 \%$ of chopped alfalfa hay and no alfalfa silage. One diet contained (dry matter basis) $4.9 \%$ chopped alfalfa hay and $4.9 \%$ alfalfa silage. One diet contained (dry matter basis) $9.8 \%$ of alfalfa silage and no chopped alfalfa hay. Contents of crude protein, neutral detergent fiber, acid detergent fiber, and starch, averaged across diets, were 16.7, 41.3, 21.1 , and $24.4 \% \mathrm{DM}$, respectively, and did not differ significantly among diets. Replacing chopped alfalfa hay with alfalfa silage decreased the proportion of dietary DM passing through the 8-mm screen of the Penn State Particle Separator from 61.9 to $55.2 \%$ dry matter and significantly increased dietary physical effective NDF (peNDF) content, calculated as the NDF retained by the two screens of the Penn State Particle Separator, from 20.1 to $23.3 \%$ DM. Replacing chopped alfalfa hay with alfalfa silage also reduced dietary DM content, increased rumen $\mathrm{pH}$ from 6.27 to 6.47 , reduced volatile fatty acid concentrations, numerically increased milk fat concentration and milk fat yield. Milk yield, milk protein concentration, dry matter intake, and rumen ammonia concentration were not affected.
\end{abstract}

(Key words: rumen $\mathrm{pH}$, neutral detergent fiber, particle size, dairy cow)

Abbreviation key: $\mathbf{A H}=$ diet containing chopped alfalfa hay, AHAS = diet containing both chopped alfalfa

Received February 3, 2003.

Accepted June 17, 2003.

Corresponding author: J. C. Plaizier; e-mail: plaizier@Ms. Umanitoba.CA. hay and alfalfa silage, $\mathbf{A S}$ = diet containing alfalfa silage, $\mathbf{p e N D F}=$ physically effective NDF, $\mathbf{P S P S}=$ Penn State Particle Separator; SARA = subacute ruminal acidosis.

\section{INTRODUCTION}

Physically effective NDF (peNDF) is fiber that stimulates chewing and promotes salivary buffering (Santini et al., 1983; Mertens, 1997). Physical effectiveness of a feed is based on attributes that affect chewing activity, such as NDF content, particle size, intrinsic fragility, and moisture content (Grant, 1997; Mertens, 1997). Dietary peNDF contributes to rumen buffering and helps to maintain a rumen favorable for growth of rumen bacteria, even when a high concentrate diet is fed (Van Soest, 1994). However, excess peNDF can limit feed intake (Allen, 2000).

Lammers et al. (1996) described a method for the analysis of particle sizes of forage and TMR using the Penn State Particle Separator (PSPS). This method can also be used to estimate dietary peNDF contents (Yang et al., 2001; Beauchemin et al., 2003). However, a laboratory assessment of fiber effectiveness must be validated with a biological assessment of fiber effectiveness.

The amount of NDF, forage NDF, and peNDF required in a lactating dairy ration to prevent milk fat depression and ruminal acidosis has been under debate, particularly in barley-based diets (Beauchemin, 1991; Beauchemin et al., 1994a, 1994b; Beauchemin and Rode, 1997). Mertens (1997) suggested that $22 \%$ of ration DM needs to consist of peNDF in order to maintain rumen $\mathrm{pH}$ above 6.0 and that, in order to maintain a milk fat percentage of $3.4 \%$ in early to midlactation Holstein cows fed corn based diets, $20 \%$ of ration DM should be supplied by peNDF. The NRC (2001) recommends that the DM of dairy diets contain a minimum of $25 \% \mathrm{NDF}$ and $75 \%$ of the NDF should be supplied by forages. The NRC (2001) does not give requirements 
for peNDF, due to lack of standard validated methods to measure effective fiber in feeds and to establish requirements for effective fiber. NRC (2001) further concludes that before such requirements can be formulated, more research on the chemical and physical characteristics of feeds that influence their ability to maintain optimal rumen function and animal health is required.

Existing recommendations for dietary fiber content originate from experiments using corn-based diets and, therefore, do not account for differences between barley and corn such as the higher nonforage fiber content of barley (Yang et al., 2001). Differences between barley and corn nonforage fiber also include a more rapid fermentation rate of barley (McCarthy et al., 1997). Hence, it is likely that diets incorporating barley require a higher proportion of dietary peNDF and that barleybased diets containing 25\% DM NDF contain insufficient forage NDF. This was demonstrated by Beauchemin and Rode (1997), who found that the minimum amount of forage fiber required to avoid milk fat depression is higher for barley grain-based diets than for corn grain-based diets. Beauchemin (1991) also suggested that in diets containing barley-based concentrate, the NDF concentration should be increased to $32 \%$ DM because a greater proportion of the NDF originates from the concentrate. Additional research is needed before a definite recommendation for a minimum peNDF concentration in barley-based diets can be formulated.

The objectives of this experiment were to determine the effects of increasing dietary peNDF content, by replacing chopped alfalfa hay with alfalfa silage, on rumen $\mathrm{pH}$, rumen fluid composition, DMI, milk production, and milk composition of lactating dairy cows fed a TMR based on barley grain and corn silage.

\section{MATERIALS AND METHODS}

\section{Experimental Procedures}

Three primiparous and nine multiparous lactating Holstein cows, housed in a tie-stall barn at the Glenlea Research Station of the University of Manitoba, were used in a $3 \times 3$ Latin square design with three 3 -wk experimental periods. Each experimental period consisted of a 14-d adaptation period and a 7-d collection period. Animals were cared for in accordance with the Canadian Council for Animal Care (CCAC) guidelines. At the beginning of the experiment, cows averaged 128 \pm 84.3 (mean \pm SD) DIM. During the experiment cows weighed on average $700 \pm 66.3 \mathrm{~kg}$ and had an average BCS of $3.0 \pm 0.53$ (Edmondson et al., 1989).

Cows received one of three TMR diets (containing chopped alfalfa hay, both chopped alfalfa hay and alfalfa silage, or alfalfa silage; AH, AHAS, and AS, re-
Table 1. Ingredients and nutrient composition of experimental diets with varying inclusion rates of chopped alfalfa hay and alfalfa silage. ${ }^{1}$

\begin{tabular}{|c|c|c|c|c|c|}
\hline \multirow[b]{2}{*}{ Diet ingredients } & \multicolumn{3}{|c|}{ Diet (\% of DM) } & \multirow[b]{2}{*}{$\mathrm{SE}^{2}$} & \multirow[b]{2}{*}{$P$ value } \\
\hline & $\mathrm{AH}$ & AHAS & AS & & \\
\hline Sunflower seeds & 4.2 & 4.2 & 4.2 & . & \\
\hline Chopped alfalfa hay & 9.8 & 4.9 & 0.0 & . & \\
\hline Alfalfa silage & 0.0 & 4.9 & 9.8 & . & $\ldots$ \\
\hline Corn silage & 30.5 & 30.5 & 30.5 & & $\ldots$ \\
\hline Energy supplement & 38.4 & 38.5 & 38.4 & $\ldots$ & $\ldots$ \\
\hline Protein supplement & 17.0 & 17.0 & 17.0 & $\ldots$ & $\ldots$ \\
\hline \multicolumn{6}{|l|}{ Nutrient composition $^{3}$} \\
\hline $\mathrm{DM}, \%$ & $54.0^{\mathrm{a}}$ & $52.4^{\mathrm{ab}}$ & $50.1^{\mathrm{b}}$ & 1.47 & $<0.05$ \\
\hline $\mathrm{CP}, \%$ of $\mathrm{DM}$ & 16.8 & 16.4 & 16.8 & 0.63 & 0.96 \\
\hline RUP, $\%$ of $\mathrm{CP}^{4}$ & 45.8 & 45.0 & 44.9 & 1.33 & 0.44 \\
\hline $\mathrm{NDF}, \%$ of $\mathrm{DM}$ & 41.1 & 41.2 & 41.7 & 1.52 & 0.69 \\
\hline $\mathrm{ADF}, \%$ of $\mathrm{DM}$ & 20.7 & 21.9 & 20.8 & 1.27 & 0.57 \\
\hline Ether extract, \% of DM & 6.4 & 7.0 & 6.4 & 0.35 & 0.85 \\
\hline $\mathrm{Ca}, \%$ of $\mathrm{DM}$ & 1.1 & 1.0 & 1.1 & 0.06 & 0.93 \\
\hline Starch, \% of DM & 24.7 & 25.0 & 24.2 & 1.58 & 0.69 \\
\hline $\mathrm{P}, \%$ of $\mathrm{DM}$ & 0.6 & 0.6 & 0.7 & 0.01 & 0.88 \\
\hline $\mathrm{K}, \%$ of $\mathrm{DM}$ & 1.5 & 1.5 & 1.5 & 0.07 & 0.90 \\
\hline $\mathrm{Mg}, \%$ of $\mathrm{DM}$ & 0.3 & 0.3 & 0.3 & 0.01 & 0.59 \\
\hline $\mathrm{Na}, \%$ of $\mathrm{DM}$ & 0.5 & 0.5 & 0.5 & 0.02 & 0.84 \\
\hline $\mathrm{pH}$ & 5.1 & 5.1 & 5.2 & 0.2 & 0.85 \\
\hline
\end{tabular}

${ }^{\mathrm{a}, \mathrm{b}, \mathrm{c}}$ Means within a row without a common superscript $\operatorname{differ}(P<$ $0.05)$.

${ }^{1}$ Diets had equal inclusion rates of corn silage, energy supplement, protein supplement, and contained 9.8\% DM chopped alfalfa hay (AH), $4.9 \%$ DM chopped alfalfa hay, and $4.9 \%$ DM alfalfa silage (AHAS), or $9.8 \%$ DM alfalfa silage (AS).

${ }^{2}$ Where $\mathrm{n}=3$ for each treatment.

${ }^{3}$ Actual nutrient compositions of experimental diets were calculated for each period.

${ }^{4}$ Estimated from NRC (2001).

spectively) during each experimental period (Table 1). Each diet contained (DM basis) $38.5 \%$ barley grainbased energy supplement, $30.5 \%$ corn silage, $17.0 \%$ protein supplement, and $4.2 \%$ sunflower seeds. One diet also contained (DM basis) $9.8 \%$ of chopped alfalfa hay $(\mathrm{AH})$ and no alfalfa silage. One diet also contained (DM basis) $4.9 \%$ chopped alfalfa hay and $4.9 \%$ alfalfa silage (AHAS). One diet also contained (DM basis) $9.8 \%$ of alfalfa silage (AS) and no chopped alfalfa hay. The hay was chopped with a 8610 Tub Grinder (JI Case International, Racine, WI). The diets were mixed using a Data Ranger mixer (American Calan, Northwood, NH) with a Weigh Tronix weigh head (model 1000, American Calan, Northwood, NH). Diets were delivered once daily for ad libitum consumption and 5 to $10 \%$ orts. Cows had unlimited access to water.

\section{Dry Matter Intake and Feed Analyses}

Dry matter intake was determined daily for each cow. Samples of the diets and their orts were collected daily during the 7-d collection period, pooled by weight and period. Diet samples were collected daily and pooled for each collection period. Forages were sampled once 
per collection period and pooled across collection periods. The DM content of pooled diets, forages, and ort samples were determined by drying at $60^{\circ} \mathrm{C}$ for $48 \mathrm{~h}$ (AOAC, 1990). Dried feed samples were ground using a Wiley mill through a 1-mm screen (Thomas-Wiley, Philadelphia, PA) and stored at $-20^{\circ} \mathrm{C}$ until analysis.

All feed samples were analyzed for $\mathrm{CP}$ using the $\mathrm{CuSO}_{4} / \mathrm{TiO}_{2}$ mixed catalyst Kjeldahl procedure (AOAC, 1990), NDF (National Forage Testing Association, 1993) using alpha-amylase, ADF (AOAC, 1990), RUP (Licitera et al., 1999), ether extract (AOAC, 1990), and starch (McRae and Armstrong, 1968). Calcium, P, K, $\mathrm{Mg}$, and $\mathrm{Na}$ were measured by inductively coupled plasma emission spectroscopy (AOAC, 1990) using an Atom Scan 25 plasma spectrometer (Thermo Jarrell Ash Corp., Grand Junction, CO) after acid digestion. Acid detergent lignin was determined in forage samples according to AOAC (1990). The $\mathrm{pH}$ of the TMR was determined using the method described by BuchananSmith and Yao (1981). The $\mathrm{pH}$ was measured using an Accumet Basic $15 \mathrm{pH}$ meter and an Accumet gel-filled polymer body combination $\mathrm{pH}$ electrode (Fischer Scientific, Fairlawn, NJ), calibrated with $\mathrm{pH} 4.0$ and $\mathrm{pH} 7.0$ buffer solutions (Fisher Scientific, Fairlawn, NJ).

Particle size distributions were determined for all TMR, pooled refusals, and forage samples using the PSPS (Heinrichs, 1996; Lammers et al., 1996). The PSPS used was equipped with two screens and a bottom pan. The diameters of holes of the screens were 19 and $8 \mathrm{~mm}$ for the top and middle screen, respectively. Approximately 150-g wet sample was placed on the top screen of the PSPS. The PSPS was shaken for a total of 40 times ( 5 times in each direction, twice) (Heinrichs, 1996). The contents of each fraction were weighed and subsequently dried and analyzed for NDF as described earlier. The physical effectiveness factor of NDF was determined as the proportion of NDF retained on the top and middle screen, which corresponds to the NDF in the particles greater than $8 \mathrm{~mm}$. The peNDF content of the diet was calculated by multiplying the physically effective factor by the dietary NDF content.

\section{Milk Yield and Composition Analysis}

Cows were milked twice daily and milk production was determined using Tru Test regulation meters (Westfalia Surge, Mississauga, ON). Milk samples were collected from four consecutive milkings in $50-\mathrm{ml}$ vials in each collection period and preserved with 2-bromo2-nitropropane-1,3 diol. Milk samples were stored at $4^{\circ} \mathrm{C}$ until analyzed for fat and protein at the laboratory of the Manitoba Milk Producers (Winnipeg, MB) by near-infrared analysis (AOAC, 1990) using the MilkO-Scan 303AB (Foss Electric, Hillerød, Denmark).

\section{Rumen pH Measurement}

Rumen fluid was sampled twice during each collection period (Tuesday and Thursday afternoons) at 4 to $5 \mathrm{~h}$ postfeeding. Approximately $50 \mathrm{ml}$ of fluid was aspirated using a Geishauser oral probe (Geishauser, 1993; Green et al., 1999). The $\mathrm{pH}$ of rumen fluid samples were measured using an Accumet Basic $15 \mathrm{pH}$ meter and an Accumet gel-filled polymer body combination $\mathrm{pH}$ electrode (Fischer Scientific, Fairlawn, NJ), calibrated with $\mathrm{pH} 4.0$ and $\mathrm{pH} 7.0$ buffer solutions (Fisher Scientific, Fairlawn, NJ). Rumen fluid samples were centrifuged at $1900 \times g$ for $10 \mathrm{~min}$. The supernatant was frozen immediately and stored at $-20^{\circ} \mathrm{C}$ until further analysis.

\section{VFA and Ammonia Analysis}

Frozen rumen fluid samples were thawed at room temperature and $1 \mathrm{ml}$ of a $25 \%$ meta-phosphoric acid solution was added to $5 \mathrm{ml}$ of rumen fluid. The tubes were vortexed and placed in a $-20^{\circ} \mathrm{C}$ freezer for $17 \mathrm{~h}$. Thawed samples were centrifuged for $10 \mathrm{~min}$ at 1900 $\times g$. Approximately $2 \mathrm{ml}$ of supernatant was decanted into a clean dry vial. The samples were capped and placed into the autosampler device (model 8100, Varian, Walnut Creek, CA) for analysis. Concentrations of VFA were determined by gas chromatography (model 3400 Star, Varian, Walnut Creek, CA) using a 1.83m glass column (model 2-1721, Supelco, Oakville, ON) (Erwin et al., 1961). The injector and detector temperatures were set at 170 and $195^{\circ} \mathrm{C}$, and initial and final column temperatures were set at 120 and $165^{\circ} \mathrm{C}$, respectively. The runtime was 4 min followed by a 2 -min thermal stabilization period.

Ammonia nitrogen concentration of rumen fluid samples was determined using the method described by Novozamsky et al. (1974). Absorbance was read at 630 $\mathrm{nm}$ on a Pharmacia Biotech Ultraspec 2000 UV/visible spectrophotometer (Biochrom, Cambridge, UK).

\section{Statistical Analysis}

Analysis of variance for weekly averages of rumen fluid, milk, and intakes was conducted using the SAS MIXED procedure (SAS, 1990). The effects of diet and period were considered fixed; cow effects were considered random.

Analysis of variance for physical and chemical composition of diets was conducted using the same model, with the exception that the cow effect was excluded. Statistical significance was set at a $P$ value of equal to or less than 0.05. Differences among treatment means were tested for significance using Tukey's multiple range test (SAS, 1990). 
Table 2. Ingredient composition energy supplement and protein supplement (\% of DM).

\begin{tabular}{|c|c|c|}
\hline Ingredient & $\begin{array}{l}\text { Energy } \\
\text { supplement } \\
\text { (\% of DM) }\end{array}$ & $\begin{array}{l}\text { Protein } \\
\text { supplement } \\
\text { (\% of DM) }\end{array}$ \\
\hline Rolled barley & 54.0 & $\ldots$ \\
\hline Luprosil salt & 0.2 & $\ldots$ \\
\hline Protein pellet ${ }^{1}$ & 1.9 & $\ldots$ \\
\hline Dairy supplement ${ }^{2}$ & 40.0 & $\ldots$ \\
\hline Tallow & 4.0 & $\ldots$ \\
\hline Dried distillers grains & $\ldots$ & 42.0 \\
\hline Fish meal & $\ldots$ & 7.0 \\
\hline Canola meal & $\ldots$ & 22.8 \\
\hline Soybean meal & $\ldots$ & 20.0 \\
\hline Beet molasses & $\ldots$ & 3.0 \\
\hline Niacin & $\ldots$ & 0.3 \\
\hline Sodium bicarbonate & $\ldots$ & 5.0 \\
\hline
\end{tabular}

${ }^{1}$ Protein pellets contains $46.1 \%$ soybean meal, $2.6 \%$ wheat shorts, $40.0 \%$ canola meal, $5.0 \%$ oat hulls, $0.3 \%$ pellet binder, $1.0 \%$ cane molasses, and $5.0 \%$ corn gluten meal.

${ }^{2}$ Dairy supplement contains $0.13 \%$ vitamin $\mathrm{ADE}$ premix, $0.14 \%$ trace mineral premix, $2.6 \%$ soybean meal, $0.06 \%$ selenium, $39.1 \%$ wheat shorts, $5.0 \%$ distillers' grain, $17.5 \%$ canola meal, $15.0 \%$ ground wheat, $1.7 \%$ dicalcium phosphate, $1.6 \%$ salt, $2.0 \%$ dynamate, $0.3 \%$ pellet binder, $1.0 \%$ cane molasses, $3.7 \%$ calcium carbonate, and $10.0 \%$ corn gluten meal.

\section{RESULTS}

Compositions of the diets, the protein and energy supplements, and the forages are given in Tables 1, 2, and 3. Replacing chopped alfalfa hay with alfalfa silage reduced DM (Table 1). Crude protein, RUP, NDF, ADF, starch, ether extract, and minerals were not affected (Table 1). Chopped alfalfa had more feed particles pass the PSPS 8-mm screen than did alfalfa silage or corn silage (Table 4). As a result, replacing chopped alfalfa hay with alfalfa silage reduced diet DM passing the 8$\mathrm{mm}$ screen from 61.9 to $55.2 \% \mathrm{DM}(P<0.05)$ and increased the dietary peNDF content from 20.1 to $23.3 \%$ DM $(P<0.05)$ (Table 5). The NDF content of the three PSPS fractions were not different among diets. NDF contents averaged across diets were 62.3, 47.2, and

Table 3. Nutrient composition of the forages included in the experimental diets with varying rates of chopped alfalfa hay and alfalfa silage.

\begin{tabular}{lccc}
\hline Chemical component & Corn silage & Alfalfa silage & Alfalfa silage \\
\hline DM\% & 29.0 & 47.2 & 87.3 \\
\cline { 2 - 4 } & & & \\
\cline { 2 - 4 } CP & 7.7 & 17.3 & of $\mathrm{DM})$ \\
\cline { 3 - 4 } NDF & 58.9 & 56.5 & 16.9 \\
ADF & 34.3 & 47.1 & 57.4 \\
Acid detergent lignin & 3.0 & 8.6 & 46.4 \\
Starch & 19.4 & 12.3 & 6.9 \\
Ca & 0.28 & 1.12 & 11.8 \\
P & 0.27 & 0.30 & 0.13 \\
K & 1.30 & 3.01 & 2.45 \\
Mg & 0.19 & 0.29 & 0.18 \\
\hline
\end{tabular}

32.6\% DM, in the 19- screen, 8-mm screen, and bottom pan fraction of the PSPS, respectively. Neutral detergent fiber content differed significantly $(P<0.001)$ among PSPS fractions. Analysis of particle size distribution of the TMR and orts is shown in Figure 1. The orts had a greater $(P<0.05)$ proportion of particles that were retained by the 19- and 8-mm PSPS screens compared with the TMR. However, the difference between particle size distribution of TMR and the respective orts was not $(P=0.31)$ affected by diet.

Replacing chopped alfalfa hay with alfalfa silage in the TMR also increased rumen $\mathrm{pH}$ from 6.27 to 6.47 ( $P$ $<0.05)$ and decreased $(P<0.05)$ total VFA concentration from 97.1 to $79.8 \mathrm{~m} M \mathrm{~L}^{-1}$ (Table 6). This replacement also reduced $(P<0.05)$ ruminal acetate, butyrate, and propionate concentrations. Ruminal ammonia concentration was not changed.

Replacing chopped alfalfa hay with alfalfa silage did not affect DMI, quantity of refusal, milk yield, milk protein percentage, and milk protein yield but tended to increase milk fat percentage $(P=0.16)$ and milk fat yield $(P=0.22$ ) (Table 7$)$. Milk fat percentages were below $2.63 \%$ for all dietary treatments.

\section{DISCUSSION}

Chopped alfalfa hay was replaced with alfalfa silage to increase the dietary peNDF content. This replacement reduced the proportion of fine $(<8 \mathrm{~mm})$ feed particles (Table 4) and the dietary DM content, without changing the dietary $\mathrm{CP}, \mathrm{RUP}, \mathrm{NDF}, \mathrm{ADF}$, ether extract, $\mathrm{Ca}, \mathrm{P}, \mathrm{Mg}, \mathrm{K}$, and $\mathrm{Na}$ contents and diet $\mathrm{pH}$ (Table 1). Hence, differences in production and rumen conditions among diets are mainly attributed to physical differences among diets. Fine dry particles of the chopped hay could have adhered to the wetter feedstuffs, thereby preventing these particles from passing the 8-mm PSPS screen. Nonetheless, the difference in particle size distribution between the $\mathrm{AH}$ and AS diets (Table 4) indicates that this adherence was not substantial.

In this study the peNDF content of the diet was calculated as the proportion of dietary NDF retained by the 8- and 19-mm PSPS screens. Yang et al. (2001) and Beauchemin et al. (2003) calculated peNDF as the proportion of DM retained by the 8- and 19-mm PSPS screens multiplied by the overall NDF content. This calculation assumes uniformity of NDF over PSPS fractions. However, in his study NDF differed among PSPS fractions (Table 4). Hence, the NDF was not uniformly distributed over all particle sizes. The proportion of the DM retained by the 8 - and $19-\mathrm{mm}$ PSPS screens was smaller than the proportion of NDF retained by these screens (Table 4). As a result, peNDF based on the 
Table 4. Least square means of Penn State Particle Separator (PSPS) determinations of experimental diets with varying inclusion rates of chopped alfalfa hay and alfalfa silage. ${ }^{1}$

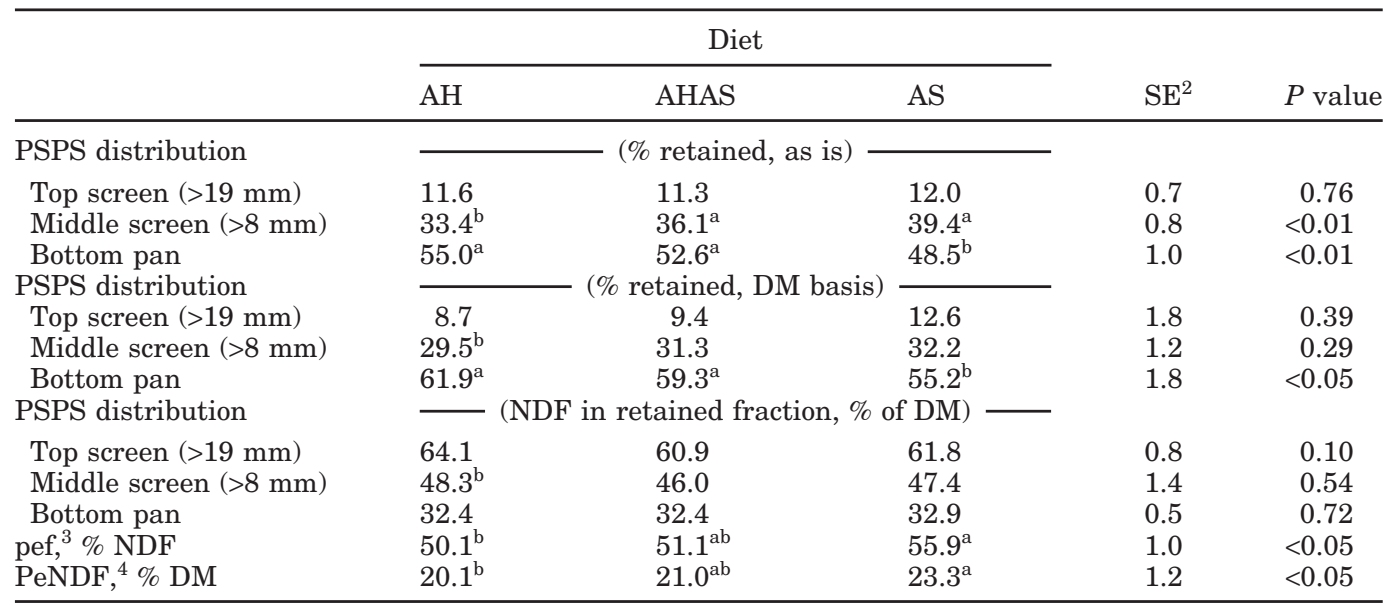

${ }^{\mathrm{a}, \mathrm{b}, \mathrm{c}}$ Means within a row without common superscript differ $(P<0.05)$.

${ }^{1}$ Diets had equal inclusion rates of corn silage, energy supplement, protein supplement, and contained 9.8\% DM chopped alfalfa hay (AH), 4.9\% DM chopped alfalfa hay and 4.9\% DM alfalfa silage (AHAS), or $9.8 \% \mathrm{DM}$ alfalfa silage (AS).

${ }^{2}$ Where $\mathrm{n}=3$ for each treatment.

${ }^{3}$ pef $=$ proportion of NDF retained by the screens of the Penn State Particle Separator.

${ }^{4}$ peNDF $=$ pef multiplied by dietary NDF content.

retained DM was lower than peNDF based on the retained NDF. It is assumed that peNDF based on retained NDF is a more accurate indicator of rumen buffering capacity than peNDF based on retained DM.

The proportion of particles retained by the 8- and 19mm PSPS screens was greater for the orts than for the TMR (Figure 1). This indicates that cows selected against large feed particles in favor of finer feed particles and the proportion of the diet ingested by cows was less coarse than the TMR. Therefore, to determine the effects of peNDF in dairy cows, selection must be considered.

The difference between the rumen $\mathrm{pH}$ of the $\mathrm{AH}$ and AS diets shows that rumen $\mathrm{pH}$ increased when chopped

Table 5. Least square means of Penn State Particle Separator (PSPS) determinations of forages included in the experiment with varying reate3d of chopped alfalfa hay and alfalfa silage. Analysis of forages included in the experimental diets. ${ }^{1}$

\begin{tabular}{|c|c|c|c|}
\hline & Corn silage & Alfalfa silage & Alfalfa hay \\
\hline PSPS sieving & \multicolumn{3}{|c|}{$\longrightarrow$ (\% retained, as is $) \longrightarrow$} \\
\hline Top screen (>19 mm) & 11.9 & 26.6 & 31.4 \\
\hline Middle screen $(>8 \mathrm{~mm})$ & 56.4 & 44.6 & 24.6 \\
\hline Bottom pan & 31.7 & 28.8 & 44.1 \\
\hline PSPS sieving & \multicolumn{3}{|c|}{ (\% retained, DM basis) } \\
\hline Top screen (>19 mm) & 12.6 & 30.0 & 31.6 \\
\hline Middle screen $(>8 \mathrm{~mm})$ & 54.1 & 41.1 & 24.6 \\
\hline Bottom pan & 33.3 & 28.9 & 43.8 \\
\hline
\end{tabular}

${ }^{1}$ Penn State Particle Size distributions were calculated for each period $(n=3)$ for each treatment. alfalfa hay was completely replaced with alfalfa silage (Table 6). This coincided with a decrease in ruminal VFA (Table 6) and an increase in peNDF (Table 4). This agrees with Owens et al. (1998) who concluded that rumen $\mathrm{pH}$ is affected by the total VFA concentration in rumen fluid. It is assumed that replacing chopped alfalfa hay with alfalfa silage also increased rumen bicarbonate levels, since a reduction in the proportion of fine feed particles stimulates chewing activity and

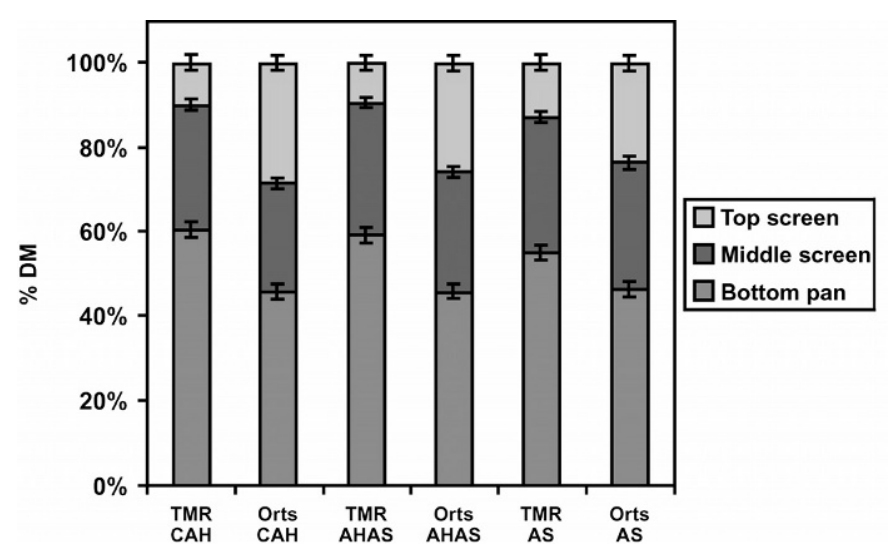

Figure 1. Penn State Particle Separator distribution after wet sieving of experimental diets and their respective orts. Diets had equal inclusion rates of corn silage, energy supplement, and protein supplement and contained 9.8\% DM chopped alfalfa hay (AH), $4.9 \%$ DM chopped alfalfa hay and $4.9 \%$ DM alfalfa silage (AHAS), or $9.8 \%$ DM alfalfa silage (AS). 
Table 6. Rumen fluid composition of lactating Holstein cows fed experimental diets with varying inclusion rates of chopped alfalfa hay and alfalfa silage. ${ }^{1}$

\begin{tabular}{lcccccc}
\hline & \multicolumn{3}{c}{ Diet } & & \\
\cline { 2 - 4 } Item $^{2}$ & $\mathrm{AH}$ & AHAS & $\mathrm{AS}$ & & SE & $P$ value \\
\hline $\mathrm{pH}$ & $6.27^{\mathrm{a}}$ & $6.35^{\mathrm{ab}}$ & $6.47^{\mathrm{b}}$ & 0.04 & $<0.01$ \\
VFA, $\mathrm{m} M \mathrm{~L}^{-1}$ & & & & & \\
Total & $97.1^{\mathrm{a}}$ & $88.3^{\mathrm{a}}$ & $79.8^{\mathrm{b}}$ & 2.2 & $<0.05$ \\
Acetate & $55.7^{\mathrm{a}}$ & $51.7^{\mathrm{a}}$ & $46.9^{\mathrm{b}}$ & 1.3 & $<0.01$ \\
Propionate & $26.2^{\mathrm{a}}$ & $24.1^{\mathrm{b}}$ & $21.2^{\mathrm{b}}$ & 0.6 & $<0.01$ \\
Butyrate & $12.0^{\mathrm{a}}$ & $9.6^{\mathrm{ab}}$ & $8.8^{\mathrm{b}}$ & & 0.7 & $<0.01$ \\
Other & 3.2 & 2.9 & 2.9 & 0.1 & 0.16 \\
Ruminal ammonia, $\mathrm{mg} \mathrm{dl}{ }^{-1}$ & 6.57 & 7.46 & 5.56 & 0.61 & 0.10 \\
\hline
\end{tabular}

a,b,c Means within a row without common superscript differ $(P<0.05)$.

${ }^{1}$ Diets had equal inclusion rates of corn silage, energy supplement, protein supplement and contained 9.8\% DM chopped alfalfa hay ( $\mathrm{AH})$, $4.9 \% \mathrm{DM}$ chopped alfalfa hay and $4.9 \% \mathrm{DM}$ alfalfa silage (AHAS), or $9.8 \% \mathrm{DM}$ alfalfa silage (AS).

${ }^{2}$ Average rumen fluid composition for each animal within each period $(\mathrm{n}=12)$.

saliva production (Cassida and Stokes, 1986; Beauchemin et al., 1994b; Mertens, 1997). Volatile fatty acid concentrations were low compared with those observed in other studies with lactating dairy cows (Yang et al., 2001; Beauchemin et al., 2003). This can be explained by higher NDF and lower starch contents of the diets in our study when compared to the earlier studies.

Our results agree with Beauchemin et al. (2003), who also found an effect of forage particle size on rumen pH. However, Yang et al. (2001) did not find such an effect. This discrepancy could possibly be due to differences in the range of dietary particle sizes among studies. Beauchemin et al. (2003) found the proportion of particles retained by the PSPS screens ranged from 21.9 to $41.3 \%$ DM, whereas Yang et al. (2001) found

Table 7. Milk production and feed intake of lactating Holstein cows fed experimental diets experimental diets with varying inclusion rates of chopped alfalfa hay and alfalfa silage. ${ }^{1}$

\begin{tabular}{|c|c|c|c|c|c|}
\hline \multirow[b]{2}{*}{ Item $^{2}$} & \multicolumn{3}{|c|}{ Diet } & \multirow[b]{2}{*}{ SE } & \multirow[b]{2}{*}{$P$ value } \\
\hline & $\mathrm{AH}$ & AHAS & AS & & \\
\hline DMI, $\mathrm{kg} \mathrm{d}^{-1}$ & 21.94 & 23.49 & 23.93 & 1.42 & 0.58 \\
\hline Orts, $\% \mathrm{~d}^{-1}$ of feed provided & 7.29 & 6.47 & 8.04 & 0.95 & 0.52 \\
\hline Milk yield, $\mathrm{kg} \mathrm{d}^{-1}$ & 39.2 & 38.9 & 39.1 & 0.44 & 0.89 \\
\hline \multicolumn{6}{|l|}{ Milk Components } \\
\hline Fat, $\%$ & 2.39 & 2.53 & 2.63 & 0.14 & 0.16 \\
\hline Fat yield, $\mathrm{kg} \mathrm{d}^{-1}$ & 0.93 & 0.98 & 1.02 & 0.05 & 0.22 \\
\hline Protein, \% & 3.18 & 3.21 & 3.26 & 0.06 & 0.40 \\
\hline Protein yield, $\mathrm{kg} \mathrm{d}^{-1}$ & 1.23 & 1.23 & 1.25 & 0.03 & 0.70 \\
\hline
\end{tabular}

${ }^{\mathrm{a}, \mathrm{b}, \mathrm{c}}$ Means within a row without common superscript $\operatorname{differ}(P<$ $0.05)$.

${ }^{1}$ Diets had equal inclusion rates of corn silage, energy supplement, protein supplement and contained $9.8 \% \mathrm{DM}$ chopped alfalfa hay (AH), $4.9 \% \mathrm{DM}$ chopped alfalfa hay and $4.9 \% \mathrm{DM}$ alfalfa silage (AHAS), or $9.8 \% \mathrm{DM}$ alfalfa silage (AS).

${ }^{2}$ Averages for each animal within each period $(n=12)$. that this proportion ranged from 32.5 to $39.1 \%$ DM. Diets with very fine particles were included in the former study, but not in the study from Yang et al. (2001). These results agree with Mertens (1997), where the relationship between peNDF and rumen $\mathrm{pH}$ is quadratic, and that the effect of peNDF on rumen $\mathrm{pH}$ is limited at higher peNDF levels. In our experiment, the proportion of particles retained by the PSPS screens ranged from $38.1 \% \mathrm{DM}$ in the $\mathrm{AH}$ diet to $44.8 \% \mathrm{DM}$ in the AS diet (Table 4). Hence, diets in our study were generally coarser than those used by both Yang et al. (2001) and Beauchemin et al. (2003). Therefore, factors other than the distribution of particle size, such as digestion rate and intrinsic buffering capacity (McBurney et al., 1983) of the forages contributed to differences among these studies. The forages used by Yang et al. (2001) and Beauchemin et al. (2003) were alfalfa silage, alfalfa hay, and barley silage, whereas corn silage was the main forage used in our study. Because corn silage has a lower intrinsic buffering capacity than alfalfa silage and alfalfa hay (McBurney et al., 1983), a larger effect of peNDF on rumen $\mathrm{pH}$ can be expected in corn silage-based diets compared with alfalfa-based diets.

The differences in chemical composition and physical composition among diets did not affect DMI (Table 7). Yang et al. (2001) and Beauchemin et al (2003) also did not observe that forage particle length affected DMI in high concentrate diets. Beauchemin et al. (1994b) observed that reducing the particle size of alfalfa silage affected DMI in high forage diets, but not in low forage diets. Soita et al. (2002) found that reducing the particle size of barley silage increased DMI in steers fed an allforage diet. In the current experiment, the combined inclusion rate of the energy supplement, the protein supplement, and the sunflower seeds constituted $59.7 \%$ of the diet DM. In such high concentrate diets, metabolic constraints, rather than physical constraints, limit short-term voluntary feed intake (Sheperd and Combs, 1998; Allen, 2000). A reduction in particle size will have a larger effect on voluntary feed intake in forage-based diets than in concentrate-based diets.

Diet did not affect milk yield, milk protein percentage, and milk protein yield (Table 7). This agrees with Beauchemin et al. (2003), who found that in the range between 21.9 and $41.3 \% \mathrm{DM}$, peNDF does not affect milk yield and milk protein content. Krause et al. (2002) also found that differences in mean particle size between 3.0 and $6.3 \mathrm{~mm}$ did not affect milk production. To understand the effect of peNDF and dietary particle size distribution on milk production, the relationship between effective fiber and ruminal and total tract digestibilities needs to be determined (Yang et al., 2001).

Milk fat contents and milk fat yields were low compared to what is normally observed in Holstein cows 
(NRC, 2001) and only increased numerically when chopped alfalfa hay was replaced with alfalfa silage and when peNDF was increased (Table 7), despite of the decrease in rumen acetate (Table 6). Mertens (1997) compiled data from 36 citations and observed a positive correlation between dietary peNDF content, rumen $\mathrm{pH}$, and milk fat percentage. It has been recently theorized that low rumen $\mathrm{pH}$ increases the production of transfatty acids that reduce de novo milk fat synthesis (Griinari et al., 1998). Observations from Griinari et al. (1998) can also explain why the reduction in acetate did not result in a decrease in milk fat content, as the presence of trans-fatty acids and not the availability of precursors could have limited de novo milk fat synthesis. The difference in the relationship between peNDF and milk fat content between the study from Mertens (1997) and our research could be due to the wider range of peNDF.

The lowest rumen $\mathrm{pH}$ of 6.27 was observed in the $\mathrm{AH}$ diet (Table 6). This would indicate that cows did not experience subacute ruminal acidosis (SARA) (Keunen et al., 2002). Also, the dietary contents of NDF and starch (Table 1) do not suggest that cows were at risk of ruminal acidosis (NRC, 2001). However, the low milk fat content and the inversion of milk fat and milk protein contents (Table 6) could be regarded as indicators of SARA (NRC, 2001). To explain this disparity, differences in the accuracy of the diagnosis of SARA based on rumen $\mathrm{pH}$ measurement and milk fat content need to be considered. In our experiment, $\mathrm{pH}$ was measured in rumen fluid samples collected using an oral probe, 4 to $5 \mathrm{~h}$ after feeding. Due to the high diurnal variation in rumen $\mathrm{pH}$, continuous rumen $\mathrm{pH}$ monitoring provides a more accurate diagnosis of SARA than $\mathrm{pH}$ measurement in rumen fluid samples collected once daily (Yang et al., 2001; Keunen et al., 2002). The availability of rumen-fistulated lactating cows is often a constraint in production trials. In non-rumen-fistulated cows, collection of rumen fluid by oral probe or by rumenocentesis can be used to monitor rumen conditions (Duffield et al., 2000). The lowest point in rumen $\mathrm{pH}$ can be expected 4 to $5 \mathrm{~h}$ after feeding (Keunen et al, 2002) for diagnosing SARA.

When interpreting the $\mathrm{pH}$ of rumen fluid samples, which can be used for differences between the techniques used for the collection of these samples must be taken into account. Keefe and Ogilvie (1997) observed that ruminal $\mathrm{pH}$ values obtained using the Geishauser oral probe (Geishauser, 1993) were $0.42 \mathrm{pH}$ units higher than values obtained with rumenocentesis. Duffield et al. (2000) found in lactating dairy cows that $\mathrm{pH}$ of rumen fluid samples obtained with an oral rumen probe were on average 0.35 units higher than $\mathrm{pH}$ of rumen fluid samples obtained with rumenocentesis and 0.13 units higher than the $\mathrm{pH}$ of rumen fluid samples obtained from the caudal ventral rumen via the rumen cannula. These differences in $\mathrm{pH}$ can be attributed to the saliva content in the collected rumen fluid samples and to the site in the rumen from which the samples were collected (Duffield et al., 2000). In the current study, the same probe and technique were used as in the study from Green et al. (1999) and Duffield et al. (2000). Saliva contamination of the rumen fluid samples was considered minimal. According to Cumby et al. (2001) and Keunen et al. (2002), rumen samples taken from the ventral sac of rumen fistulated cows with a pH below 5.6 are likely to indicate SARA. Based on previous experience with the rumen fluid collection with the oral probe (Green et al., 1999; Duffield et al., 2000 ), it is not believed that the $\mathrm{pH}$ of collected rumen fluid samples were indicative of a $\mathrm{pH}$ below 5.6 in the ventral sac of the rumen at the time of sampling.

Milk fat content is affected by many dietary and genetic factors, in addition to rumen $\mathrm{pH}$ and dietary peNDF content (Santini et al., 1986; Yang et al., 2001). All diets contained $4.2 \%$ sunflower seeds, which contained $41.9 \%$ unsaturated fat and added over $1 \%$ of unsaturated fat to the diet. The addition of unsaturated fat to high-concentrate diets can cause milk fat depression (Griinari et al., 1998). This can, at least in part, explain the low milk fat that was observed. Also, the selection program used by the Glenlea Research Station has selected for low milk fat content in dairy cattle for many years. As milk fat content can be affected by many factors other than peNDF and rumen $\mathrm{pH}$, measurement of rumen $\mathrm{pH}$ is a more suitable indicator for the development of dietary peNDF recommendations than milk fat content.

Mertens (1997) concludes that the physical effectiveness of fiber is more critical in high concentrate/low forage diets compared with low concentrate/high forage diets to prevent ruminal acidosis. The ratio between forage and concentrate of a diet is easy to determine if only forages and concentrates are fed. However, if diets contain grain crop silages such as corn silage or barley silage, that contain both forage and concentrate, then this ratio is more difficult to estimate. The inclusion rates of energy supplement, protein supplement, and corn silage in the current study suggest a high concentrate/low forage diet. However, the starch content of the corn silage was very low compared to the NFC content of corn silages reported by (NRC, 2001). Guidelines for the dietary peNDF contents should be established on the basis of measured NDF and NFC contents, rather than on the basis of estimated ratio between forage and concentrate. 


\section{CONCLUSIONS}

Replacing $9.8 \%$ of DM as chopped alfalfa hay with alfalfa silage in a TMR containing barley grain and corn silage increased dietary peNDF from 20.1 to $23.3 \%$ $\mathrm{DM}$, reducing dietary DM. Dietary contents of CP, RUP, $\mathrm{NDF}, \mathrm{ADF}$, starch ether extract, and minerals content were not affected. Replacing chopped alfalfa hay with alfalfa silage also increased rumen $\mathrm{pH}$ from 6.27 to 6.47 , reduced ruminal VFA, tended to increase milk fat percentage and milk fat yield. Milk yield, milk protein content, milk protein yield, and DMI were not affected. Because NDF varied among PSPS fractions, peNDF was calculated as the NDF retained by the 8- and 19mm PSPS sieves. The differences between peNDF of TMR and orts showed that, as expected, cows will select for finer feed particles. Rumen pH, along with dietary NDF and starch concentrations did not suggest SARA was induced, although milk fat content was lower for the chopped alfalfa hay diet. Because milk fat depression can be caused by factors other than low rumen $\mathrm{pH}$, such as the addition of unsaturated fat to the diet and genetics, it is not an accurate indicator of rumen acidity. Nonetheless, measures of $\mathrm{pH}$ from rumen fluid samples collected 4 to $5 \mathrm{~h}$ after feeding are a reliable indicator of SARA. Differences in sampling technique, e.g., through a cannula, rumenocentesis, or a stomach tube, need to be considered.

Guidelines for dietary peNDF contents depend on the contents and the source of dietary NDF and NFC. Additional research into the interactions between these factors on production and health of dairy cows is required before these guidelines can be finalized.

\section{ACKNOWLEDGMENTS}

The staff of the Glenlea Research Station, University of Manitoba, Terri Garner and Janice Haines, are thanked for their technical assistance. The Manitoba Milk Producers (MMP) are thanked for the milk composition analyses. This study was supported by grants from Dairy Farmers of Canada (DFC) and the Natural Sciences and Engineering Research Council of Canada (NSERC).

\section{REFERENCES}

Allen, M. S. 2000. Effects of diet on short-term regulation of feed intake by lactating dairy cattle. J. Dairy Sci. 83:1598-1624.

AOAC. 1990. Association of Official Analytical Chemists. Official Methods of Analysis. 15th ed. AOAC, Arlington, VA.

Beauchemin, K. A. 1991. Effects of dietary neutral detergent fiber concentration and alfalfa hay quality on chewing, rumen function, and milk production of dairy cows. J. Dairy Sci. 74:3140-3151.

Beauchemin, K. A., B. I. Farr, and L. M. Rode. 1991. Enhancement of the effective fiber content of barley-based concentrates fed to dairy cows. J. Dairy Sci. 74: 3128-3139.
Beauchemin, K. A., B. I. Farr, L. M. Rode, and G. B. Schaalje. 1994a. Optimal neutral detergent fiber concentration of barley-based diets for lactating dairy cows. J. Dairy Sci. 77:1013-1029.

Beauchemin, K. A., B. I. Farr, L. M. Rode, and G. B. Schaalje. 1994b. Effects of alfalfa silage chop length and supplementary long hay on chewing and milk production of dairy cows. J. Dairy Sci. 77:1326-1339.

Beauchemin, K. A., and L. M. Rode. 1997. Minimum versus optimum concentrations of fiber in dairy cow diets based on barley silage and concentrates of corn or barley. J. Dairy Sci. 80:1629-1639.

Beauchemin, K. A., W. Z. Yang, and L. M. Rode. 2003. Effects of particle size of alfalfa based dairy cow diets on chewing activity, ruminal fermentation, and milk production. J. Dairy Sci. 86:630-643.

Buchanan-Smith, J. G., and Y. T. Yao. 1981. Effect of additives containing lactic acid bacteria and/or hydrolytic enzymes with an antioxidant upon the preservation of corn or alfalfa silage. Can. J. Anim. Sci. 61:669-680.

Cassida, K. A., and M. R. Stokes. 1986. Eating and resting salivation in early lactating dairy cows. J. Dairy Sci. 69:1282-1292.

Cumby, J. L., J. C. Plaizier, I. Kyriazakis, and B. W. McBride. 2001. Effect of subacute ruminal acidosis on the preference of cows for pellets containing sodium bicarbonate. Can. J. Anim. Sci. 81:149-152.

Duffield, T., J. C. Plaizier, R. Bagg, G. Vessie, P. Dick, and B. W. McBride. 2000. A comparison of techniques to measure rumen $\mathrm{pH}$ in lactating dairy cattle. J. Dairy Sci. 83(Suppl. 1):42. (Abstr.)

Edmondson, A. J., I. J. Lean, L. D. Weaver, T, Farver, and G. Webster. 1989. A body condition scoring chart for Holstein dairy cows. J. Dairy Sci. 72:68-78.

Erwin, E. S., G. J. Marco, and E. M. Emery. 1961. Volatile fatty acids analysis of blood and rumen fluid by gas chromotography. J. Dairy Sci. 44:1768.

Geishauser, T. 1993. An instrument for collection and transfer of ruminal fluid and for administration of water soluble drugs in adult cattle. Bovine Pract. 27:38-42.

Grant, R. J. 1997. Interactions among forages and nonforage fiber sources. J. Dairy Sci. 80:1438-1446.

Green, B. L., B. W. McBride, D. Sandals, K. E. Leslie, R. Bagg, and P. Dick. 1999. The impact of a monensin controlled-release capsule on subclinical ketosis in the transition dairy cow. J. Dairy Sci. 82:333-342.

Griinari, J. M., D. A. Dwyer, M. A. McGuire, D. E. Bauman, D. L. Palmquist, and K. V. Nurmela. 1998. Trans-octadecenoic acids and milk fat depression in lactating dairy cows. J. Dairy Sci. 81:1251-1261.

Heinrichs, J. 1996. Pages 1-9 in Evaluating Particle Size of Forages and TMRs using the Penn State Particle Size Separator. Pennsylvania State University, State College.

Keefe, G. P., and T. H. Ogilvie. 1997. Comparison of oro-rumenal probe and rumenocentisis for prediction of rumen $\mathrm{pH}$ in dairy cattle. Pages 168-169 in Proceedings. 30th Annual Convention of the American Association of Bovine Practitioners, Rome, GA.

Keunen, J. E., J. C. Plaizier, I. Kyriazakis, T. F Duffield, T. M. Widowski, M. I. Lindinger, and B. W. McBride. 2002. Effects of a subacute ruminal acidosis model on the diet selection of dairy cows. J. Dairy Sci. 85:3304-3313.

Krause, K. M., D. K. Combs, and K. A. Beauchemin. 2002. Effects of forage particle size and grain fermentability in midlactation cows. I. Milk production and diet digestibility. J. Dairy Sci. 85:19361946.

Lammers, B. P., D. R. Buckmaster, and A. J. Heinrichs. 1996. A simple method for the analysis of particle sizes of forages and total mixed rations. J. Dairy Sci. 79:922-928.

Licitera G., P. J. Van Soest, I. Schadt, S. Carpino, and G. J. Sniffen. 1999. Influence of the concentration of the protease from Streptomyces griseus relative to rumen protein degradability. Anim. Feed Sci. Technol. 77:99-113.

McBurney, M. I., P. J. Van Soest, and L. E. Chase. 1983. Cation exchange capacity and buffering capacity of neutral detergent fibres. J. Sci. Food Agric. 34:910-916. 
McCarthy, R. D., Jr., T. H. Klusmeyer, J. L. Vicini, J. H. Clark, and D. R. Nelson. 1989. Effects of source of protein and carbohydrate on ruminal fermentation and passage of nutrients to the small intestine of lactating cows. J. Dairy Sci. 72:2002-2016.

McRae, J. C., and D. G. Armstrong. 1968. Enzyme methods for determination of $\alpha$-linked glucose polymers in biological materials. J. Sci. Food Agric. 19:578-581.

Mertens, D. R. 1997. Creating a system for meeting the fiber requirements of dairy cows. J. Dairy Sci. 80:1463-1481.

National Forage Testing Association. 1993. Forage analysis procedures. Procedure 5.1.

NRC. 2001. National Research Council. Nutrient Requirements of Dairy Cattle. 7th rev. ed. National Acad. Sci. Washington, DC.

Novozamsky, I., R. Van Eck, J. C. H. Schouwenburg, and F. Walinga. 1974. Total nitrogen determination in plant material by means of the indole-phenol blue method. Neth. J. Agric. Sci. 22:3-5.

Owens, F. N., D. S. Secrist, W. J. Hill, and D. R. Gill, 1998. Acidosis in cattle: A review. J. Anim. Sci. 76:275-286.
Santini, F. J., A. R. Hardie, and N. A. Jorgensen. 1983. Proposed use of adjusted intake based on forage particle length for calculation of roughage indexes. J. Dairy Sci. 66:811-820.

SAS. 1990. SAS User's Guide. Statistics. Version 6 Edition. 1990. SAS Inst., Inc., Cary, NC.

Sheperd, A. C., and D. K. Combs. 1998. Long-term effects of acetate and propionate on voluntary feed intake by midlactation cows. J. Dairy Sci. 81:2240-2250.

Soita, H. W., D. A. Christensen, J. J. McKinnon, and A. F. Mustafa. 2002. Effects of barley silage of different theoretical cut length on digestion kinetics in ruminants. Can. J. Anim. Sci. 82:207-213.

Van Soest, P. J. 1994. Nutritional Ecology of the Ruminant. 2nd ed. Cornell University Press, Ithaca, NY.

Yang, W. Z., K. A. Beauchemin, and L. M. Rode. 2001. Effects of grain processing, forage to concentrate ratio, and forage particle size on rumen $\mathrm{pH}$ and digestion by dairy cows. J. Dairy Sci. 84:2203-2216. 